\section{Involvement of Viral Nervous Necrosis in Larval Mortality of Hatchery-reared Pacific Bluefin Tuna Thunnus olientalis}

\author{
Toyohiro Nishioka ${ }^{1 *}$, Koh-ichiro Mori ${ }^{2}$, Takuma \\ Sugaya $^{2}$, Nobuhiro Tezuka ${ }^{3}$, Takayuki Takebe ${ }^{4}$, \\ Hitoshi Imaizumi ${ }^{5}$, Kazunori Kumon ${ }^{6}$, \\ Shukei Masuma ${ }^{7}$ and Toshihiro Nakai ${ }^{8}$ \\ ${ }^{1}$ National Research Institute of Aquaculture, Fisheries \\ Research Agency, Mie 516-0193, Japan \\ ${ }^{2}$ National Research Institute of Aquaculture, Fisheries \\ Research Agency, Oita 879-2602, Japan \\ ${ }^{3}$ Notojima Station, National Center for Stock Enhancement, \\ Fisheries Research Agency, Ishikawa 926-0216, Japan \\ ${ }^{4}$ Seikai National Fisheries Research Institute, Ishigaki \\ Tropical Station, Fisheries Research Agency, \\ Okinawa 907-0451, Japan \\ ${ }^{5}$ Shibushi Station, National Center for Stock Enhancement, \\ Fisheries Research Agency, Kagoshima \\ 899-7101, Japan \\ ${ }^{6}$ Amami Station, National Center for Stock Enhancement, \\ Fisheries Research Agency, Kagoshima \\ 894-2414, Japan \\ ${ }^{7}$ Miyazu Station, National Center for Stock Enhancement, \\ Fisheries Research Agency, Kyoto 626-0052, Japan \\ ${ }^{8}$ Graduate School of Biosphere Science, \\ Hiroshima University, Hiroshima \\ 739-8528, Japan
}

(Received November 23, 2009)

\begin{abstract}
Amami Station of Fisheries Research Agency, Japan has experienced mass mortalities of Pacific bluefin tuna Thunnus olientalis in the process of seed production since around 2000 . The mortalities mostly occurred at larval stages. In some cases of the mortalities, but not all cases, the diseased fish was characterized by vacuolation in the central nervous systems and retina, and a betanodavirus (RGNNV genotype) was detected in the affected fish by PCR and FAT methods and culture isolation. The present results suggest that VNN can be a cause of larval mortality of Pacific bluefin tuna.
\end{abstract}

Key words: betanodavirus, viral nervous necrosis, Thunnus olientalis, Pacific bluefin tuna, mass mortality

\footnotetext{
* Corresponding author

E-mail: toyohiro@affrc.go.jp
}

The Pacific bluefin tuna Thynnus orientalis is the largest species of the family Scombridae, reaching body sizes of more than $650 \mathrm{~kg}$. The tuna migrates actively in Pacific Ocean ${ }^{1)}$ and is of great economic value as fisheries animal worldwide. The global catches of tunas were over 640 million metric tons in $2006^{2)}$, and a part of natural resources of Pacific bluefin tuna is in a precipitous decline because of overexploitation.

In Japan, aquaculture of Pacific bluefin tuna was begun in a project supported by Japan Fisheries Agency, named as "Experiments on the development of tunas culture techniques", in $1970^{3)}$. The project research started first in the Fisheries Laboratory of Kinki University, one facility of the project, where wild-caught juveniles (100-500 g in body weight) were used as seeds for aquaculture. After a variety of techniques for broodstock rearing and natural spawning were studied, larval production trials have been initiated since 1979 using naturally spawned eggs in that facility ${ }^{4)}$. On the other hand, the Japanese Government, the member of the Western and Central Pacific Fisheries International Conservation (WCPFC), has also implemented to develop the seed production technique for the purpose of stock enhancement. This project was started at Amami Station, National Center for Stock Enhancement (NCSE) of Japan Fisheries Agency, in 1997 ${ }^{5}$. Through efforts of these tuna research projects, useful information on hatchery programs of Pacific bluefin tuna was accumulated. However, number of fingerlings produced is still very limited at any hatcheries, mainly due to high mortality in larvae from mouth opening to around 20 days post-hatching with unknown causes ${ }^{6,7)}$.

It is anticipated that multiple factors have a part in larval mortality of Pacific bluefin tuna. In 1997-1999, soon after seed production operation at the NCSE Amami Station, unusual mass mortalities were frequently recorded in fish at larval stages. We first suspected implication of viral nervous necrosis (VNN) to the mortality, since the disease due to piscine nodavirus (Betanodavirus, Nodaviridae) has caused mortalities in hatchery-reared larvae and juveniles of various marine fish species ${ }^{8,9)}$, and succeeded in detecting the coat protein gene of betanodavirus in the diseased larvae and juveniles ${ }^{10)}$. In order to reveal involvement of VNN in the mortality of Pacific bluefin tuna, we investigated the mortality cases encountered during seed production at the NCSE Amami Station since 2000.

\section{Materials and Methods}

Four groups of broodstocks of Pacific bluefin tuna were kept at the Amami Station located in Kakeroma Island, Kagoshima Prefecture. One group of broodstocks has been reared in a cove (Nakata Bay) closed by barrier net $\left(140 \times 10^{3} \mathrm{~m}^{2}\right)$ since 1993 , and the other three groups have been reared in circle net pens $(40 \mathrm{~m}$ 
in the diameter) outside the barrier net in the cove since 1993, 1996 and 2004, respectively. Fish were spawned naturally in either closed cove or net pens, and spawned floating eggs were collected using a $243-\mu \mathrm{m}$ mesh net. In addition to eggs spawned at the Amami Station, those spawned at other facilities were partly used. The eggs were disinfected with iodine $(50-70$ $\mathrm{mg} / \mathrm{L}$ for $1-2 \mathrm{~min})$, ozone $(0.2-0.6 \mathrm{mg} / \mathrm{L}$ in total residual oxidant) or hypochlorite (50 mg/L for $1 \mathrm{~min}$ ) and kept in 200-L or 500-L tanks under a flow-through system using sea water treated by UV (Chiyoda Kohan Co., Ltd.), ozonizer (Ebara Jitsugyo Co., Ltd.) or electrolyzation (Towa Denki Seisakusho Co., Ltd.). Hatched larvae were transferred to $50-\mathrm{m}^{3}$ concrete tanks, and

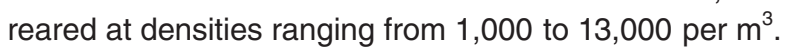
Larvae and juveniles were fed with rotifer Brachionus plicatilis, artemia Artemia salina nauplii, larvae of spangled emperor Lethrinus nebulosus or Japanese parrotfish Oplegnathus fasciatus, and minced frozen juvenile Japanese sand lance Ammodytes personatus as they grow. Water temperature was controlled not to be come less than $25^{\circ} \mathrm{C}$, with some exceptions.

Freshly dead larvae at 19 days post-hatching (dph) and juveniles at $33 \mathrm{dph}$, which were collected during the mortality cases in 2000 , were fixed with $10 \%$ buffered formalin and embedded in paraffin wax. The sections of $5 \mu \mathrm{m}$ were subjected to a histopathological staining with hematoxylin-eosin and an indirect fluorescent antibody test (FAT) with a rabbit antiserum against striped jack nervous necrosis virus (SJNNV) which was used in the previous studies ${ }^{11}$.

Collected abnormal fish (moribund and dead) in 2000-2002 or apparently normal fish in 2002-2008 were stored at $-80^{\circ} \mathrm{C}$ until use for polymerase chain reaction (PCR) tests. Total RNA was extracted from each lot of larvae (pooled whole body consisting of 5-20 fish) or juveniles (individual brain or eye) using ISOGEN (Nippon gene) according to the manufacture's direction. Reverse transcription (RT)-PCR was carried out to detect the coat protein gene (RNA2) of betanodavirus with a primer set (F2 and R3) by the method described previously ${ }^{12)}$. These PCR primers were available to amplify $\mathrm{T} 4$ region (about $400 \mathrm{bp}$ ) of any genotypes of betanodavirus, i.e. SJNNV, RGNNV (redspotted nervous necrosis virus), TPNNV (tiger puffer nervous necrosis virus), and BFNNV (barfin flounder nervous necrosis virus) ${ }^{13)}$. RT-PCR amplicons of T4 region were then subjected to nested PCR amplification using internal primers specific to betanodavirus RGNNV genotype; RG-668f (5'-ACCTGAGGAGACTACCGCTC$3^{\prime}$ ) and RG-919r (5'-CAGCGAAACCAGCCTGCAGG-3'). Amplified DNA was analyzed by $2 \%$ Nusieve-agarose (3:1) gel electrophosis. Isolation and titration of betanodavirus were performed with the diseased larvae in 2002 using E-11 cells ${ }^{14)}$, according to the methods previously described ${ }^{15)}$. Cytopathic effects (CPE) were observed at $25^{\circ} \mathrm{C}$ for 10 days and the $50 \%$ tissue culture infectious dose $\left(\mathrm{TCID}_{50}\right)$ was calculated.

\section{Results and Discussion}

At the Amami Station, after mass mortalities in 1997-1999, similar unusual mortalities have repeatedly occurred in larvae without any apparent diseased signs under water temperature ranging from $23^{\circ} \mathrm{C}$ to $29^{\circ} \mathrm{C}$, irrespective of the broodstock groups used. Mortalities were also observed in fish at juvenile stages, which showed abnormal swimming behavior such as whirling, sinking to the bottom and fell away from a school of fish. Fish collected from some mortality cases from 2000 to 2002 were subjected to histopathological and virological examinations. Histopathological changes were not clear in the central nervous systems and retina of the larvae (19 dph, $\mathrm{n}=5$ ) but strong FAT-positive signals were detected in the brain and retina, while conspicuous tissue vacuolation was observed in the brain, spinal cord and retina of the juvenile ( $33 \mathrm{dph}, \mathrm{n}=5)$ and strong FAT-positive signals were also detected in these affected tissues (Fig. 1). The vacuolation in the central nervous systems and retina is well known as a typical sign in VNN-affected fish ${ }^{8,9)}$. Specific fluorescence with the anti-SJNNV serum indicates the presence of betanodavirus antigens. The CPE, characterized by vacuolar, granular formation in the cytoplasm as previously described ${ }^{13)}$, was observed in E-11 cells inoculated with filtered fish homogenate from some mortality cases. When 10 diseased larvae with $17 \mathrm{dph}$ in 2002 were examined individually for virus isolation and titration, the virus titres ranged from $10^{5.3}$ to $10^{9.6} \mathrm{TCID}_{50} / \mathrm{g}$. This wide variation in the virus titre was also reported in other fish species naturally infected with betanodavirus $\left(\right.$ RGNNV) ${ }^{16)}$.

Table 1 shows the results of RT-PCR detection of betanodavirus in moribund and dead larvae in 2000-2002. The virus was detected in fish with 6-30 dph in 48 cases $(78.7 \%)$ of 61 cases examined. These results suggest that betanodavirus infection was partly responsible for the larval and juvenile mortality of Pacific bluefin tuna at the Amami station in 2000-2002. Infection experiment of healthy larvae or juveniles with the virus isolates remains to demonstrate the viral etiology. In addition, betanodavirus isolated from Pacific bluefin tuna was also identified as RGNNV by sequence analysis of the RNA2 ${ }^{10)}$. It was well documented that betanodaviruses isolated from warm-water fishes all belonged to the RGNNV genotype ${ }^{11,17)}$.

In order to further investigate implication of betanodavirus infection in larval mortality of Pacific bluefin tuna, the prevalence of betanodavirus in apparently normal larvae $(0-30 \mathrm{dph})$ was surveyed by RT-PCR and nested PCR in 2002-2008 (Table 2). Detection rates of the virus were always higher in nested PCR than RT- 

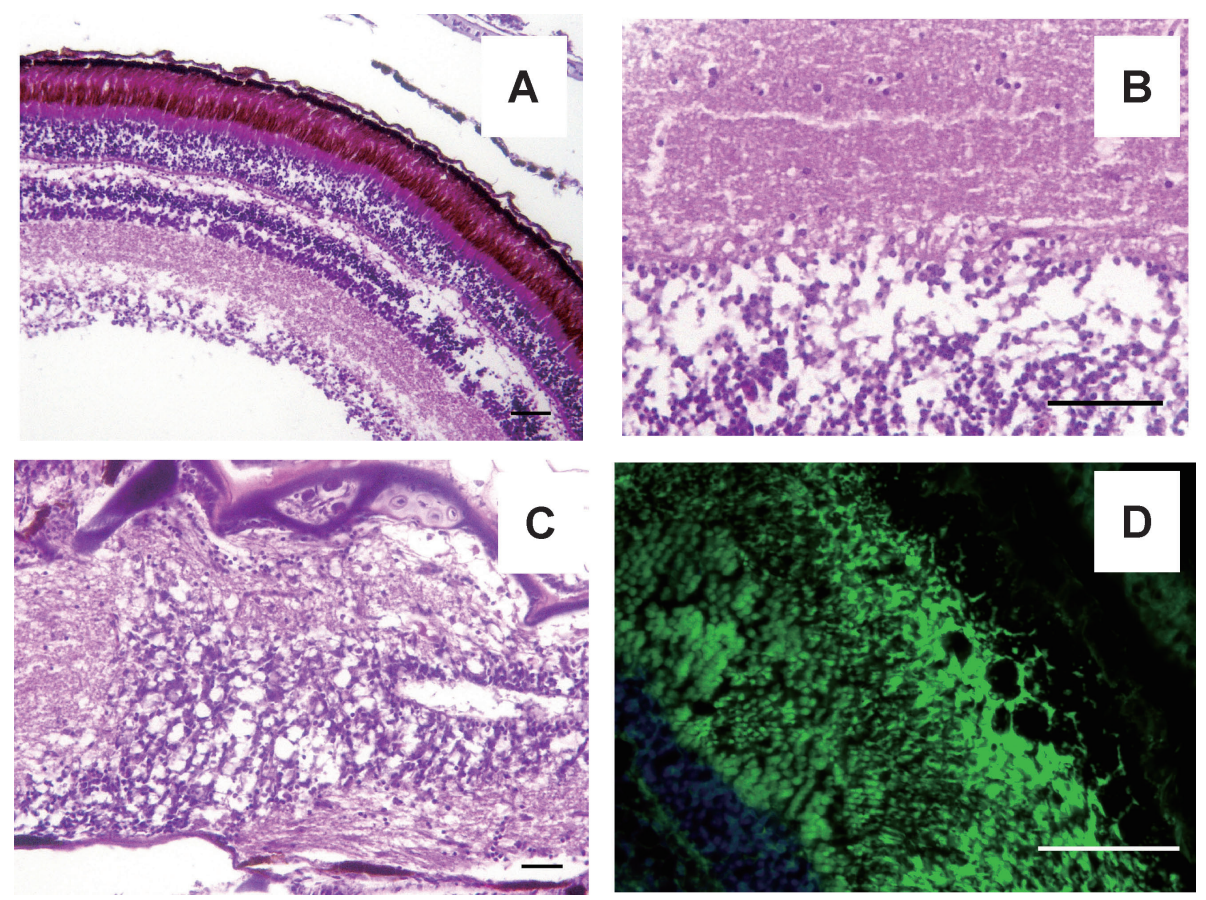

Fig. 1. Light microscopy showing tissue vacuolation and specific fluorescence in an affected juvenile (33 dph) of Pacific bluefin tuna. Hematoxylin-eosin staining: retina (A), spinal cord (B) and brain (C); FAT with anti-SJNNV serum: retina (D). Scale bar $=50$ $\mu \mathrm{m}$

PCR. They were relatively low in fish at $0-5 \mathrm{dph}$ and fish at $21-30 \mathrm{dph}$, i.e. $2.8 \%(10.5 \%)$ and $4.2 \%(11.0 \%)$ for RT-PCR (nested PCR), respectively, while those in fish at 6-20 dph were high, i.e. $16.5-23.6 \%$ for RT-

Table 1. RT-PCR detection of betanodavirus in diseased larvae of Pacific bluefin tuna produced at Amami Station in 2000-2002

\begin{tabular}{cccccc}
\hline \multirow{2}{*}{ Year } & \multicolumn{5}{c}{ Days post hatching } \\
\cline { 2 - 6 } & $0-5$ & $6-10$ & $11-15$ & $16-20$ & $21-30$ \\
\hline 2000 & & & & $7 / 7$ & $3 / 4$ \\
2001 & & & $0 / 6$ & $1 / 1$ & \\
2002 & $0 / 1^{*}$ & $6 / 6$ & $7 / 8$ & $12 / 16$ & $12 / 12$ \\
Total & $0 / 1$ & $6 / 6$ & $7 / 14$ & $20 / 24$ & $15 / 16$ \\
\hline
\end{tabular}

* Number of betanodavirus-positive cases/examined by RTPCR
PCR and 23.6-33.0\% for nested PCR. These high infection rates of apparently normal fish suggest easy shift to overt infection, leading to mass mortality. Considering that mass mortality less occurred at juvenile stages, Pacific bluefin tuna might be most susceptible to betanodavirus at the larval stages, as is striped jack Pseudocaranx dentex ${ }^{18)}$.

The previous papers demonstrated that broodstocks are the major source of betanodavirus infection in hatchery-reared larvae or juveniles of striped jack, sea bass Dicentrarchus labrax, barfin flounder Verasper moseri, and halibut Hippoglossus hippoglossus ${ }^{8,9)}$. Sugaya et al. (2009) ${ }^{10)}$ also suggested vertical transmission of betanodavirus in Pacific bluefin tuna, because the virus populations from diseased fish and broodstocks from which the larvae originated were closely

Table 2. PCR-detection of betanodavirus in apparently normal larvae and juveniles of Pacific bluefin tuna produced at Amami Station in 2002-2008

\begin{tabular}{|c|c|c|c|c|c|}
\hline \multirow{3}{*}{$\begin{array}{l}\text { Year } \\
2002\end{array}$} & \multicolumn{5}{|c|}{ Days post hatching } \\
\hline & $0-5$ & $6-10$ & $11-15$ & $16-20$ & $21-30$ \\
\hline & $2 / 46 \quad(9 / 46)^{*}$ & $19 / 33 \quad(27 / 33)$ & $6 / 11 \quad(7 / 11)$ & $9 / 13 \quad(9 / 13)$ & $5 / 8 \quad(7 / 8)$ \\
\hline 2003 & $0 / 12 \quad(12 / 12)$ & $0 / 2 \quad(2 / 2)$ & $1 / 5 \quad(5 / 5)$ & $\mathrm{ND}^{* *}$ & ND \\
\hline 2005 & $0 / 6 \quad(0 / 6)$ & $(0 / 8)$ & $0 / 11 \quad(7 / 11)$ & $(1 / 7)$ & $0 / 70 \quad(0 / 70)$ \\
\hline 2007 & $0 / 33 \quad(3 / 33)$ & $17 / 30 \quad(18 / 30)$ & $0 / 1 \quad(0 / 1)$ & $16 / 16 \quad(16 / 16)$ & $0 / 15 \quad(5 / 15)$ \\
\hline 2008 & $7 / 228(10 / 228)$ & $13 / 224(23 / 224)$ & $12 / 75 \quad(12 / 75)$ & $0 / 70 \quad(9 / 70)$ & $0 / 25 \quad(1 / 25)$ \\
\hline \multirow{2}{*}{ Total } & $9 / 325(34 / 325)$ & $49 / 297(70 / 297)$ & 19/103 (31/103) & $25 / 106(35 / 106)$ & $5 / 118(13 / 118)$ \\
\hline & $2.8 \% \quad(10.5 \%)$ & $16.5 \%(23.6 \%)$ & $18.4 \%(30.1 \%)$ & $23.6 \%(33.0 \%)$ & $4.2 \%(11.0 \%)$ \\
\hline
\end{tabular}

* Number of RGNNV-positive cases/examined by RT-PCR (nested PCR for RGNNV)

** No data 
related to their RNA2 haplotype distributions. More complete ozone-based disinfection system of eggs and rearing sea water, which have been established for VNN of striped jack ${ }^{19}$, should be examined to prevent vertical transmission of the virus in seed production of Pacific bluefin tuna. However, as RT-PCR was negative in not a few cases of larval mortalities and the virus titres were relatively lower in some dead larvae, it is probable that factors other than VNN, i.e. unsuitable rearing condition and inadequate live feeds ${ }^{6)}$ contribute to mortality.

\section{Acknowledgments}

We are grateful to $\mathrm{H}$. Obana, M. Oka, M. Arimoto and T. Iwamoto for the useful suggestions to this study and A. K. Gaafer for his technical support on the histopathological examination. This work was supported in part by a grant-in-aid for Scientific Research (18076) from the Ministry of Agriculture, Forestry and Fisheries of Japan.

\section{References}

1) Orange, C. J. and B. D. Fink (1963): Calif. Fish Game, 49 , 307-308. 2) FAO (2008): FAO, Rome, pp. 3-84. 3) Kumai, H. (1997): Suisanzoshoku, 45, 293-297. 4) Kumai, H. (1998): Nippon Suisan Gakkaishi, 64, 601-605. 5) Masuma, S., N. Tezuka, M. Koiso, T. Jinbo, T. Takebe, H. Yamazaki, H. Obana, K. Ide, H. Nikaido and H. Imaizumi (2006): Bull. Fish. Res. Agen., Supplement No. 4, 157-171. 6) Sawada, Y., T. Okada, S. Miyashita, O. Murata and H. Kumai (2005): Aquacult. Res., 36, 413-421. 7) Masuma, S., S. Miyashita, H. Yamamoto and H. Kumai (2008): Rev. Fish. Sci., 16, 385-390. 8) Munday, B. L., J. Kwang and N. Moody (2002): J. Fish Dis., 25, 127-142. 9) Nakai, T., K. Mori, T. Sugaya, T. Nishioka, K. Mushiake and H. Yamashita (2009): Bamidgeh, 61, 198-207. 10) Sugaya, T., K. Mori, T. Nishioka, S. Masuma, M. Oka, K. Mushiake, Y. Okinaka and T. Nakai (2009): J. Fish Dis., 32, 815-823. 11) Mori, K., T. Mangyoku, T. Iwamoto, M. Arimoto, S. Tanaka and T. Nakai (2003): Dis. Aquat. Org., 57, 19-26. 12) Nishizawa, T., K. Mori, T. Nakai, I. Furusawa and K. Muroga (1994): Dis. Aquat. Org., 18, 103-107. 13) Nishizawa, T., K. Mori, M. Furuhashi, T. Nakai, I. Fususawa and K. Muroga (1995): J. Gen. Virol., 76, 1563-1569. 14) Iwamoto, T., T. Nakai, K. Mori, M. Arimoto and I. Furusawa (2000): Dis. Aquat. Org., 43, 81-89. 15) Tanaka, S., I. Kuriyama, T. Nakai and T. Miyazaki (2003): J. Fish Dis., 26, 109-115. 16) Curtis, P. A., M. Drawbridge, T. Iwamoto, T. Nakai, R. P. Hedrick and A. P. Gendron (2001): J. Fish Dis., 24, 263-271. 17) Nishizawa, T., M. Furuhashi, T. Nagai, T. Nakai and K. Muroga (1997): Appl. Environ. Microbiol., 63, 1633-1636. 18) Arimoto, M., K. Maruyama and I. Fususawa (1994): Fish Pathol., 29, 19-24. 19) Mori, K., K. Mushiake and M. Arimoto (1998): Fish Pathol., 33, 443-444. 